\title{
Public Debt and Economic Growth in the Balkan Countries
}

\author{
Amarda Kadia \\ European University of Tirana
}

\begin{abstract}
In order to empirically verify the impact of public debt on economic growth we have chosen an empirical model that is based on a conditional convergence equation that relates the GDP per capita growth rate to the level of income per capita and the savings as a percentage of the GDP. We are checking the non-linear impact of government debt on the economic growth of a country. We have chosen a sample of 9 Western Balkan countries, namely, Albania, Bosnia \& Herzegovina, Bulgaria, Croatia, Macedonia, Montenegro, Romania, Serbia, Slovenia. We find that public debt has a negative effect on the economic growth, yet, this effect is dependent on the cost of debt. If the debt is used to create jobs that will eventually stimulate consumption, then the capital repayment and the interest costs will most probably not jeopardize the economic situation or increase the taxes to repay the debt. Additionally, if the growth of the real interest rate of debt is higher than the real GDP growth, this will lead to the increase of the debt/GDP ratio.
\end{abstract}

Keywords: public, debt, economic, growth, Balkan

\section{Introduction}

Public debt is one of the most important macroeconomic indicators due to its impact on the economy of each country. Literature suggests that the effect varies in each country depending on the level of economic development and situation. Public debt will have a direct impact on a country's economic growth, but there are contrasting opinions amongst economists regarding the use of public debt, particularly in situations of distress and in developing countries. The two main lines of thought are: the theory of debt neutrality and conventional theory, which will be explained in detail in the following chapters.

Stiglitz (2007) argues that it is crucial for developing countries such as the Balkans to recognize that besides posing a huge burden on the economy, public debt can cause an economic downturn leading up to the bankruptcy of a country (case of Moldova and Argentina).

However, according to him, this situation is attributed to not only the economic conditions, but also to the irresponsible lenders that fail to accurately analyze a country's solvency and the quality of the investments for which the debt has been used. It is sometimes the lenders themselves who encourage the policy makers to borrow more than what they can handle. Consequently, there is more room for the policymakers to undertake corrupt activities by abusing the borrowed funds. Typical cases are the use of debt for road infrastructure or other major works. Generally, the sizeable funds that support the policies stimulating the economic development encourage corrupt behaviour of public officials (Acconcia \& Cantabene, 2008). 


\section{Literature Review}

The economic literature that addresses the macroeconomic effects of government debt is divided into two main lines of thinking: the theory of debt neutrality and the conventional theory (Elmendorf \& Mankiw, 1999).

The theory of debt neutrality is based on the Ricardian equivalence according to which, public debt has no long-term effect on aggregate demand (Modigliani, 1961). The idea that debt is seen as a shifting of tax burden to future generations is also supported by Barro (1979), which excludes the effects in the long run.

On the other hand, the conventional theory of government debt recognizes the existence of a correlation between public debt and economic growth through the accumulation of capital. Correlation between debt and economic growth is often used as an argument favoring a restrictive fiscal policy. The correlation in question does not explicitly state that public debt stimulates growth. Moreover, it is unknown whether high public debt limits economic growth or not.

Reinhart and Rogoff (2010) show that there is a negative correlation between public debt and economic growth, but this negative correlation is not evident, not until the public debt does exceeds $90 \%$ of GDP. The authors in question have been very cautious, saying that correlation can be a causal relationship between high debt and low economic growth.

Herndon, Ash and Pollin (2013) uncovered and highlighted some errors in the calculation of average economic growth by Reinhart and Rogoff, raising many questions about the results of Harvard economists, especially for the maximum debt limit of $90 \%$. According to the latter although there were some errors in the excel worksheet they used in their studies, their method for calculating the average economic growth is correct.

Panizza and Prebsbitero (2013) in their study of the debt-growth relationship in the developed economies concluded that there exists causality (not verifiable in all cases) and heterogeneity. According to them, this correlation is in the values: an increase with 30 percentage points of debt being associated with a decrease of 0.5 percentage points of economic growth.

In the 2014 Panizza Presbitero study, the public debt has negative causal effects on economic growth, and these effects are the same for a country like Greece, as well as for a country like Japan. Most empirical studies confirm the negative correlation of public debt growth, but the idea of a certain limit of public debt presented by Reinhard and Rogoff has not been supported.

In order to study the relation public debt - economic growth, Minea and Parent (2012) used a statistical technique that allows gradual change in the relation. By working with models that use exogenous boundaries, they came to the conclusion that it is very complex to identify, the amount of the maximum level of sustainability of public debt.

Findings

In order to empirically verify the impact of public debt on economic growth we have chosen an empirical model that is based on a conditional convergence equation that relates the GDP per capita growth rate to the level of income per capita and the savings as a percentage of the GDP. The model has been augmented to include the level of gross public debt as a percentage of the GDP. Given that using debt in linear form would not yield significant results, we have 
used a quadratic equation in debt. Thus, we are checking the non-linear impact of government debt on the economic growth of a country.

We have chosen a sample of 9 Western Balkan countries, namely, Albania, Bosnia \& Herzegovina, Bulgaria, Croatia, Macedonia, Montenegro, Romania, Serbia, Slovenia. However, some data is missing for certain countries, which is why the number of observations is 117 .

Our basic estimation equation is as follows:

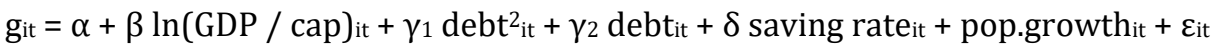

where

$\mathrm{g}_{\mathrm{it}}=$ the growth rate of GDP per capita

$\ln (\mathrm{GDP} / \mathrm{cap})_{\text {it }}=$ natural logarithm of the level of GDP per capita

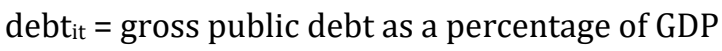

savings rate it savings as a percentage of GDP

We are going to use a fixed-effects model with panel data corrected for heteroskedasticity on the gretl program.

In order to address the potential problem of endogeneity of the debt variable, particularly reverse causation, we are going to use 2 instrumental variable estimation techniques: 1) by using lagged values of the debt-to-GDP ratio (Cecchetti, Mohanty and Zampolli, 2011); 2) by instrumenting the debt-to-GDP ratio with the average debt of the other countries in the sample (Checherita-Westphal and Rother, 2012)

Model 1: Fixed effects model, using 117 observations

Number of groups included: 9

Number of time series: $\min 11, \max 16$

Dependent variable: GDP_cap

$\begin{array}{llllll} & \text { Coefficient } & \text { Std.error } & \text { t-stat } & p \text {-value } & \\ \text { const } & -11,6760 & 4,19705 & -2,782 & 0,0064 & * * * \\ \text { SavingsasofGDP } & 0,0974268 & 0,136478 & 0,7139 & 0,4769 & \\ \text { DebtGDP_1 } & 0,164518 & 0,0967441 & 1,701 & 0,0920 & * \\ \text { DebtGDP_5 } & 0,162194 & 0,0721700 & 2,247 & 0,0267 & * * \\ \text { DebtGDPkatror } & -0,225173 & 0,102048 & -2,207 & 0,0296 & * * \\ \text { Ln(GDP_cap) } & 7,28021 \mathrm{e}-06 & 2,43053 \mathrm{e}-05 & 0,2995 & 0,7651 & \end{array}$

$\begin{array}{llll}\text { Mean dependent var } & 0,040957 & \text { S.D. dependent var } & 0,096518 \\ \text { Sum squared resid } & 0,847210 & \text { S.E. of regression } & 0,090694\end{array}$




$\begin{array}{lllr}\text { LSDV R-squared } & 0,216001 & \text { Adjusted R-squared } & 0,106476 \\ \text { LSDV F(13, 101) } & 2,182904 & \text { P-value(F) } & 0,015201 \\ \text { Log-likelihood } & 122,2711 & \text { Akaike criterion } & -216,5421 \\ \text { Schwarz criterion } & -177,8717 & \text { Hannan-Quinn } & -200,8424 \\ \text { rho } & 0,350712 & \text { Durbin-Watson } & 1,277691\end{array}$

Common test on the regressors -

Test statistic: $F(6,103)=2,04564$

With p-value $=P(F(6,103)>2,04564)=0,0661655$

Test of difference of constant of groups -

Zero hypothesis: Groups have a common constant

Test statistic: $F(7,103)=2,81981$

With $p$-value $=P(F(7,103)>2,81981)=0,00995335$

The model with 117 observations would be more robust if the times series were longer, but for the aforementioned lack of data this is all we could find. Checherita and Rother (2010) used a similar model for the developed countries in EU, whereas we are considering the Balkans, which include both developed and developing countries.

The usage of lagged terms of regressors as instruments to address endogeneity has been a common practice with macroeconomic data, but in our case it is more problematic because of the high persistency of the debt stock variable. (Checherita and Rother, 2010)

Therefore, for every country and year we have also calculated the average government debt/GDP of all the other countries in the sample and have used this variable as an instrument. Assuming that there are no strong spillover effects between debt levels in the Balkan countries and per-capita GDP growth rate in one specific country, this instrumental variable will have the advantage of not having direct causation effect on the growth rate. Additionally, the problem of endogeneity is mitigated by the fact that the debt variable is lagged to the $1^{\text {st }}$ and $5^{\text {th }}$ year.

Model 2: Fixed effects model, using 115 observations

Number of groups included: 9

Number of time series: $\min 11, \max 16$

Dependent variable: GDP_cap

$\begin{array}{lcccc} & \text { Coefficient } & \text { Std.error } & t \text {-stat } & p \text {-value } \\ \text { const } & -0,359012 & 0,280399 & -1,280 & 0,2033 \\ \text { SavingsasofGDP } & -0,0578424 & 0,147605 & -0,3919 & 0,6960\end{array}$




$\begin{array}{lllll}\text { DebtGDP_1 } & 0,0835690 & 0,119936 & 0,6968 & 0,4875 \\ \text { DebtGDP_5 } & 0,0918057 & 0,0667846 & 1,375 & 0,1723 \\ \text { DebtGDP_sq } & -0,206153 & 0,117471 & -1,755 & 0,0823 \\ \text { Ln(GDP_cap) } & 3,03891 \mathrm{e}-05 & 2,92898 \mathrm{e}-05 & 1,038 & 0,3020 \\ \text { Averageforeveryothe } & 0,244601 & 0,104141 & 2,349 & 0,0208\end{array}$

rcountry

Mean dependent var

Sum squared resid

LSDV R-squared

$\operatorname{LSDV} F(13,101)$

Log-likelihood

Schwarz criterion

rho
0,040904

0,860039

0,203997

1,991068

118,3254

$-170,2218$

0,386370
S.D. dependent var

S.E. of regression

Adjusted R-squared

P-vaue(F)

Akaike criterion

Hannan-Quinn

Durbin-Watson
0,097353

0,092278

0,091973

0,028824

$-208,6508$

$-193,0526$

1,189857

Common test on the regressors -

Test statistic: $F(6,101)=1,70504$

With $p$-value $=P(F(6,101)>1,70504)=0,127424$

Test of difference of constant of groups -

Zero hypothesis: Groups have a common constant

Test statistic: $F(7,101)=2,25075$

With p-value $=\mathrm{P}(\mathrm{F}(7,101)>2,25075)=0,0360467$

Across both models we can see a highly statistically significant non-linear relationship between the public debt ratio and the per-capita GDP growth rate for the 9 Balkan countries we have taken into consideration, starting from 1996 to 2016.

In conclusion, public debt has a negative effect on the economic growth, yet, this effect is dependent on the cost of debt. If the debt is used to create jobs that will eventually stimulate consumption, then the capital repayment and the interest costs will most probably not jeopardize the economic situation or increase the taxes to repay the debt (Greiner and Fincke, 2009). Additionally, if the growth of the real interest rate of debt is higher than the real GDP growth, this will lead to the increase of the debt/GDP ratio.

Conclusion

After observing the literature and the results to our empirical analysis, we can say with certainty that there exists a highly statistically significant non-linear relationship between 
public debt and the economic growth and that corruption is strongly correlated with the economic growth of a country.

Additionally, our analysis has shown us that on one hand public debt can be detrimental to the economic growth given its costs. On the other hand, if the debt was used to increase the productivity of a country, pay the previous debt with the proceeds, the debt could positively affect the economy.

Recently in developing countries, everytime policymakers have increased taxes to decrease the debt they have failed miserably by increasing the deficit even more. This can be infered by taking into account the economic growth, fiscal revenues and public debt. Therefore, these developing countries are not in need of failing austerity policies, instead they are in need of those policies that can improve the way debt is managed and reduce the misuse of public finances.

Albania is a country that would be in need of a decrease of the debt/GDP ratio. This can be done through a stimulation of the economy rather than a decrease of the public debt.

The empirical analysis showed that the increase on real public debt can negatively influence the GDP, yet, we did not observe a specific level above which the effects worsened. Instead, we noticed that whenever the public debt was increasing, the cost of debt would sometimes decrease because the governments would substitute the debt borrowed from second tier banks with debt borrowed from the IMF.

Investing in sectors such as agriculture, which would set the country for more competitive products during a time when the neighbouring countries have already lost some of their competitive advantages because of the current economic crisis. Therefore, if the government were to borrow with the goal to invest in the technology in agriculture or training to increase human capital productivity, this debt would definitely increase the overall productivity of a country, wages, and later on would positively affect the consumption and economic growth.

\section{Bibliography}

[1] Abed, G. and Davoodi, H., 2002, “Corruption, Structural Reforms, and Economic Performance in the Transition Economies," Chapter 18 in Governance, Corruption, and Economic Performance, ed. by George T. Abed, and Sanjeev Gupta, (Washington: International Monetary Fund).

[2] Acconcia, A., \& Cantabene, C. (2008). A big push to deter corruption: evidence from Italy. Giornale degli Economisti e Annali di Economia, 75-102.

[3] Bagnai, A. (2013). Declino, produttività, flessibilità, euro: il mio primo maggio. Blog post: http://goofynomics. blogspot. co. uk/2013/05/declino-produttivita-flessibilitaeuro. html (Last access: 4-12-2014).

[4] Cabezon, E., End, N., Slavov, S.\& Weller, A. (2017). Albania: Selected Issues; IMF Country Report No. 17/374; November 14, 2017.

[5] Checherita-Westphal, C., \& Rother, P. (2012). The impact of high government debt on economic growth and its channels: An empirical investigation for the euro area. European Economic Review, 56(7), 1392-1405.

[6] Cooray, A., Dzhumashev, R., \& Schneider, F. (2017). How does corruption affect public debt? An empirical analysis. World development, 90, 115-127. 
[7] Friedman, E., Johnson, S., Kaufmann, D., \& Zoido-Lobaton, P. (2000). Dodging the grabbing hand: the determinants of unofficial activity in 69 countries. Journal of public economics, 76(3), 459-493.

[8] Greiner, A., \& Fincke, B. (2009). Public debt and economic growth (Vol. 11). Springer Science \& Business Media.

[9] Gupta, M. S., \& Abed, M. G. T. (2002). Governance, corruption, and economic performance. International Monetary Fund.

[10] Herndon, T., Ash, M., \& Pollin, R. (2013). Does High Public Debt Consistently Stifle Economic Growth? A Critique of Reinhart and Rogoff." Political Economy Research Institute Working Paper No.

[11] Johnson S, Kaufmann D and Shleifer A (1997) The Unofficial Economy in Transition, Brookings Papers on Economic Activity, 27, 159-239.

[12] Kaufmann, D. (2010). Can corruption adversely affect public finances in industrialized countries?. Brookings Institution, April, 19.

[13] Lambsdorff, J. G. (2003). How corruption affects productivity. Kyklos, 56(4), 457 474.

[14] Mauro P., (1995) “Corruption and growth", Quarterly Journal of Economics, vol.110, 681-712.

[15] Mauro, M. P. (1996). The Effects of Corruptionon Growth, Investment, and Government Expenditure (No. 96-98). International Monetary Fund.

[16] Mauro, P. (1998). Corruption and the composition of government expenditure. Journal of Public economics, 69(2), 263-279.

[17] Panizza, U., \& Presbitero, A. F. (2014). Public debt and economic growth: is there a causal effect?. Journal of Macroeconomics, 41, 21-41.

[18] Pattillo, C. A., Poirson, H., \& Ricci, L. A. (2002). External debt and growth (No. 20022069). International Monetary Fund.

[19] Pattillo, C. A., Poirson, H., \& Ricci, L. A. (2004). What are the channels through which external debt affects growth?

[20] Reinhart, C. M., \& Rogoff, K. S. (2010). Growth in a Time of Debt (No. w15639). National Bureau of Economic Research.

[21] Rubin, R. E., Orszag, P. R., \& Sinai, A. (2004). Sustained budget deficits: the risk of financial and fiscal disarray. In AEA-NAEFA Joint Session, Allied Social Science Associations Annual Meetings.

[22] Tanzi, V., \& Davoodi, H. (2002). Corruption, public investment, and growth. In The welfare state, public investment, and growth (pp. 41-60). Springer, Tokyo. 